\title{
The Nordre Strømfiord shear zone and theArfersiorfik quartz diorite in Arfersiorfik, the Nagssugtoqidian orogen, West Greenland
}

\author{
Kai Sørensen, John A. Korstgård,W illiam E. G lassley and Bo Møller Stensgaard
}

The N ordre Strømfjord shear zone in the fjord Arfersiorfik, central West G reenland, consists of alternating panels of supracrustal rocks and orthogneisses which together form a vertical zone up to $7 \mathrm{~km}$ wide with sinistral transcurrent, ductiledeformation, which occurred under middle amphibolitefacies conditions. The pelitic and metavolcanic schists and paragneisses are all highly deformed, while the orthogneisses appear more variably deformed, with increasing deformation evident towards the supracrustal units. The c. $1.92 \mathrm{Ga}$ Arfersiorfik quartz diorite is traceable for a distance of at least $35 \mathrm{~km}$ from the Inland Ice towards the west-south-west. Towards its northern contact with an intensely deformed schist unit it shows a similar pattern of increasing strain, which is accompanied by chemical and mineral ogical changes. The metasomatic changes associated with the shear zone deformation are superimposed on a wide range of original chemical compositions, which reflect magmatic olivine and/ or pyroxene as well as hornblende fractionation trends. The chemistry of the Arfersiorfik quartz diorite suite as a whole is comparable to that of Phanerozoic plutonic and volcanic rocks of calc-alkaline affinity.

Keywords: aeromagnetic data, Arfersiorfik quartz diorite, deformation, geochemistry, Nagssugtogidian, N ordre Strømfjord shear zone, West G reenland

\footnotetext{
K.S. \& B.M .S., Geological Survey of Denmark and G reenland, Øster Voldgade 10, D K-1350 Copenhagen K, D enmark. E-mail: ks@geus.dk J.A.K., D epartment of Earth Sciences, University of Aarhus, DK-8000 Århus C, D enmark. W.E.G., Lawrence Livermore N ational Laboratory, L-646, Livermore, CA 94550, California, U SA.
}

Thec. $1850 \mathrm{M}$ a N agssugtogidian orogen in central West Greenland, originally defined by Ramberg (1949), is built up ofboth Palaeoproterozoic and reworked Archaean rocks, and contains several prominent shear zones of $\mathrm{N}$ agssugtogidian age (Bak et al. 1975a; Connelly et al. 2000; van G ool et al. 2002). These are roughly EN E-W SW-trending, approximately linear zones of intensely deformed rocks with well-developed planar and linear tectonic fabrics. The shear zones may be up to $20 \mathrm{~km}$ wide and have a strike length of more than $150 \mathrm{~km}$, the approximate width of the ice-free coast of West Greenland. O ne of the most prominent shear zones, theN ordreStrømfjord shear zone
(Fig. 1), was described in detail by Bak et al. (1975b) and Sørensen (1983), and is a main subject of this paper.

The N ordre Strømfjord shear zone was recognised by previous authors as a sinistral shear zone mainly on the basis of deflection of fabrics and lithologies. A general observation was that open structures outside the zone be come closed and brought into paral lelism within thezone. This is apparent both in the field and especially so on regional geological maps and aerial photographs. A systematic change in the orientation of planar fabrics across the shear zone indicated that the zone is wedge-shaped in vertical profile, suggesting that the zonenarrows upwards, 


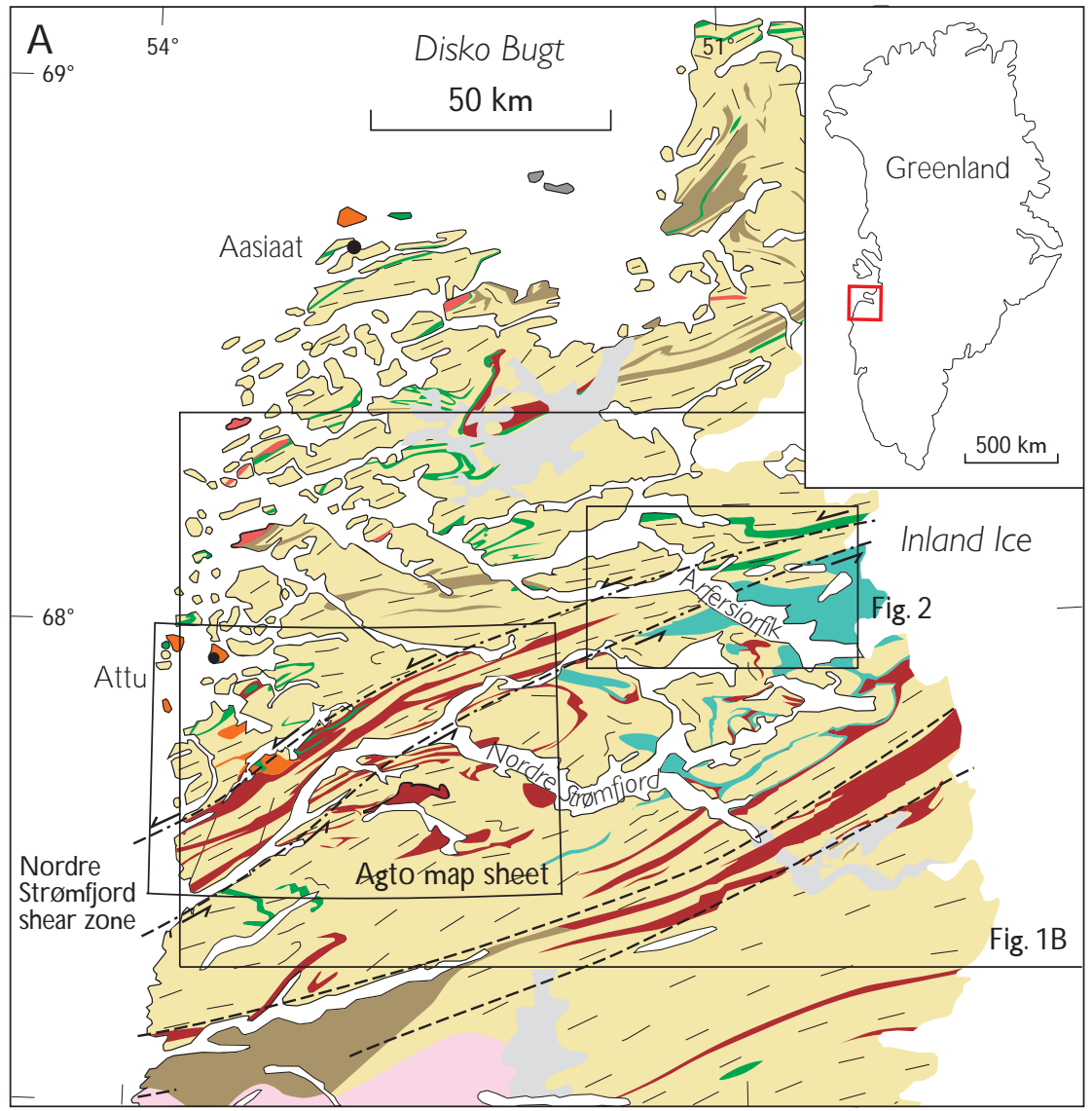

Q uaternary

Surficial deposits

Palaeogene

Basalt

$\mathrm{N}$ agssugto qidian orogen

$\square$ Sisimiut charnockite

Arfersiorfik quartz diorite

0 rthogneiss (Archaean, reworked)

Metasedimentar y rocks

(may include Archaean components)
Fig. 1. A: Simplified geological map of the Nagssugtogidian orogen. Index map of $G$ reenland shows the location of Fig. $1 \mathrm{~A}$. Black frames, locations of the Agto map sheet (0 lesen 1984) and the inner Arfersiorfik region investigated during field work in 2002 (Fig. 2). B: Aeromagnetic map of the $\mathrm{N}$ ordre Strømfjord shear zone from the coast to the western margin of the Inland Ice (shown as the vertical gradient of the total magnetic field intensity, nT / m). Anticlockwise rotation of lithologies into the shear zone is shown by curved stippled lines. The established and inferred boundaries of the high-strain part of the shear zone (full and stippled lines) are positioned where these rotating lithologies attain orientations which are indistinguishable from those within the central part of the shear zone itself. The magnetic anomaly field was obtained by subtracting the regional aeromagnetic data from the international geomagnetic reference field (Rasmussen \& van Gool 2000). N ominal flight altitude of the survey: $300 \mathrm{~m}$ above sea level, with gentle drape flying over areas with high relief. The survey was flown along $\mathrm{N}$-S flight lines $500 \mathrm{~m}$ apart and along orthogonal tielines at $5 \mathrm{~km}$ intervals. $\mathbf{n T}=$ nanotesla (magnetic flux density).

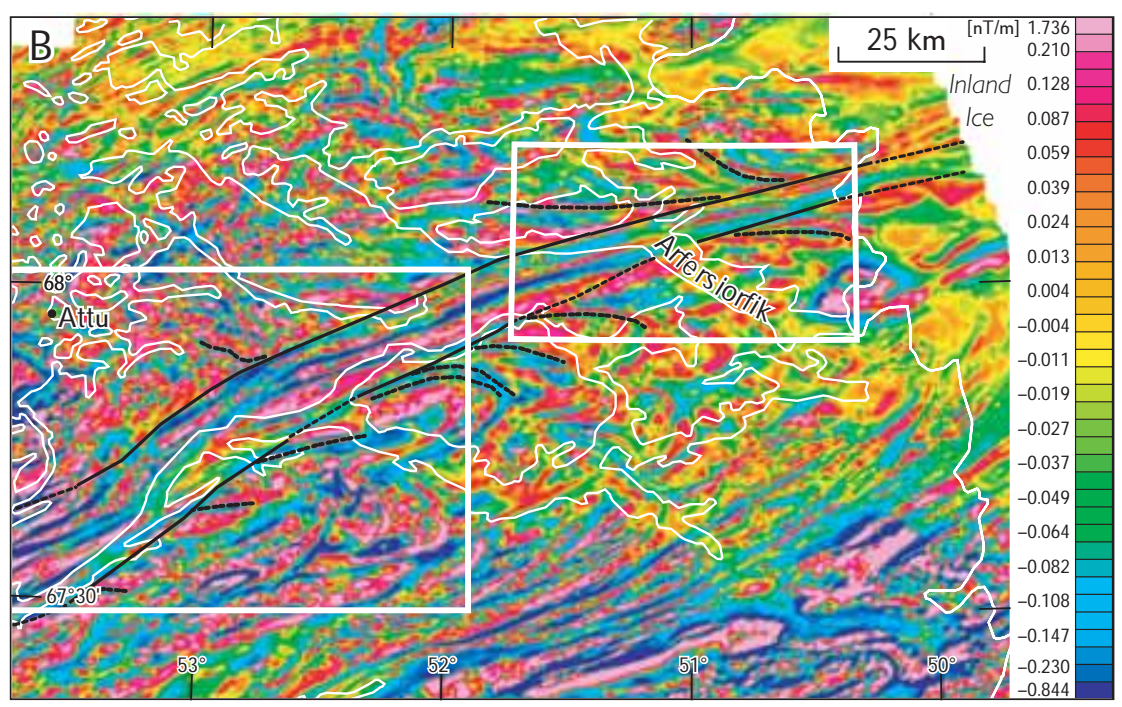


and conversely widens deeper in the crust. This interpretation is supported by the observation that the deepest part of the shear zone, which is exposed in the west near thecoast, is morethan twice aswide asitsmorehigh-level, eastern end near the Inland Ice (Bak et al. 1975a, b).

The western part of the N ordre Strømfjord shear zone was mapped in detail within the Agto map sheet (Olesen 1984). In thispaperwereport an investigation of itseastern part, conducted in 2002 in the inner part of the fjord Arfersiorfik.

0 ur investigations were in part intended to resolveconflicting interpretations of the nature of the shear zone. Although all previous published work on the shear zone had reached similar conclusions regarding its magnitude and structural character, a different hypothesis was presented in a subsequent reconnaissance study by $\mathrm{H}$ anmer et al. (1997a, b), who re-interpreted the pre-existing data and purported that the shear zone was smaller than previously mapped and accommodated less lateral displacement than previously accepted. 0 ur premise was that detailed field work aimed at resolving the spatial relationships of structural elements, rather than relying on pre viously collected data, would expand our knowledge of the characteristics of the shear zone and would enable rigorous testing of the two previous hypotheses.

The early work (Bak et al. 1975a, b; Sørensen 1983) showed the shear zone to be a large-scale synmetamorphic, sinistral transcurrent zone with a distinct wedge shape in its western, syn-granulite facies part. In that area, the shear zone is c. $15 \mathrm{~km}$ wide. It was also suggested that the shear zone deformation occurred simultaneously with large-scalemetasomatism (Sørensen \& W inter 1989). Prior to the present study, the general outline and extent of the N ordre Strømfjord shear zone between the Agto map sheet and the Inland Ice was drawn by Bak et al. (1975b) and Sørensen (1983), based on work by H enderson (1969) and interpretation of aerial photographs. N ow, the extent of thezone of high strain between the coast and the Inland Ice can be demonstrated to correlate with anticlockwise rotation of lithologies into the shear zone, which is clearly visible on a new aeromagnetic data set ( $\mathrm{N}$ ielsen $\&$ Rasmussen 2004). The age of the shear zone seems to be bracketed by the $1.85 \mathrm{G}$ a age of regional metamorphism ( $\mathrm{H}$ ickman \& G lassley 1984; C onnelly et al. 2000) and postkinematic pegmatite ages of $1.76 \mathrm{Ga}$ (C onnelly et al. 2000; Stendal et al. 2006, this volume). Apart from the shear zone, the area we investigated in 2002 also encompasses a major part of the Arfersiorfik quartz diorite (AQD ), first observed by N oe-N ygaard \& Ramberg (1961) and later described by $\mathrm{H}$ enderson (1969). The latter author visited the area in connection with reconnaissance work leading to the publication of the 1:500 000 scale geological map N ussuaq - Søndre Strømfjord (Escher 1971). T he Arfersiorfik quartz diorite was subsequently studied by Kalsbeek et al. $(1984,1987)$ and Kalsbeek $(2001)$, who interpreted it as a subduction-related calc-alkaline intrusive suite and obtained an age of intrusion of $1.92 \mathrm{G}$ a (see also the section on petrology).

Along its shores, the Arfersiorfik fjord system offers excellent exposures of the shear zone and its surroundings. The authors spent three weeks in the region in the summer of 2002, conducting their investigations from a single camp with transport by inflatable dinghy, supplemented by half a day's helicopter reconnaissance in the area between inner Arfersiorfik and the Inland Ice. The area covered during the field work is shown in Fig. 2. The main aims of the field work were to investigate the shear zone in the inner part of Arfersiorfik and to investigate the relationships between the shear zone and the Arfersiorfik quartz diorite; as can be seen from Fig. 2, the shear zone constitutes the northern boundary of the AQ D for a distance of at least $35 \mathrm{~km}$ between the Inland Ice and inner Arfersiorfik. Laboratory investigations of the approximately 110 samples collected during field work have not yet been finalised, and this account istherefore of preliminary nature.

\section{A transect through the shear zone}

Thelithology and structure of the shear zone are illustrated by way of a schematic profile covering the area between A kunnaaq and Sarfaarsuk (Fig. 3), a distance of c. 8 km, corresponding to a distance of c. $7 \mathrm{~km}$ as measured perpendicular to the shear zone trend. The shear zone is expressed by two principal characteristics: lithological units are all planar and vertically oriented, and the lithological variability per unit length across strike is much more pronounced than in the surrounding rocks north and south of the zone. In the field, these features are best displayed along the eastern shore of the small fjord O rlerfik (Fig. 2). Lithologically, the shear zone can be described as a succession of supracrustal schist and gneissunits alternating with siliceous and intermediate orthogneisses of the $A Q D$. The profile of Fig. 3 is described in the following from south to north. Further details about the AQ D are described in a later section.

To the south of the shear zone (within the area of investigation, Fig. 2) the AQD is seen to rest with low-angle boundaries on siliceous gneisses, often with an intervening screen of schist. We agree with van Gool et al. (1999) that this surface is of tectonic, probably thrust or ductile 


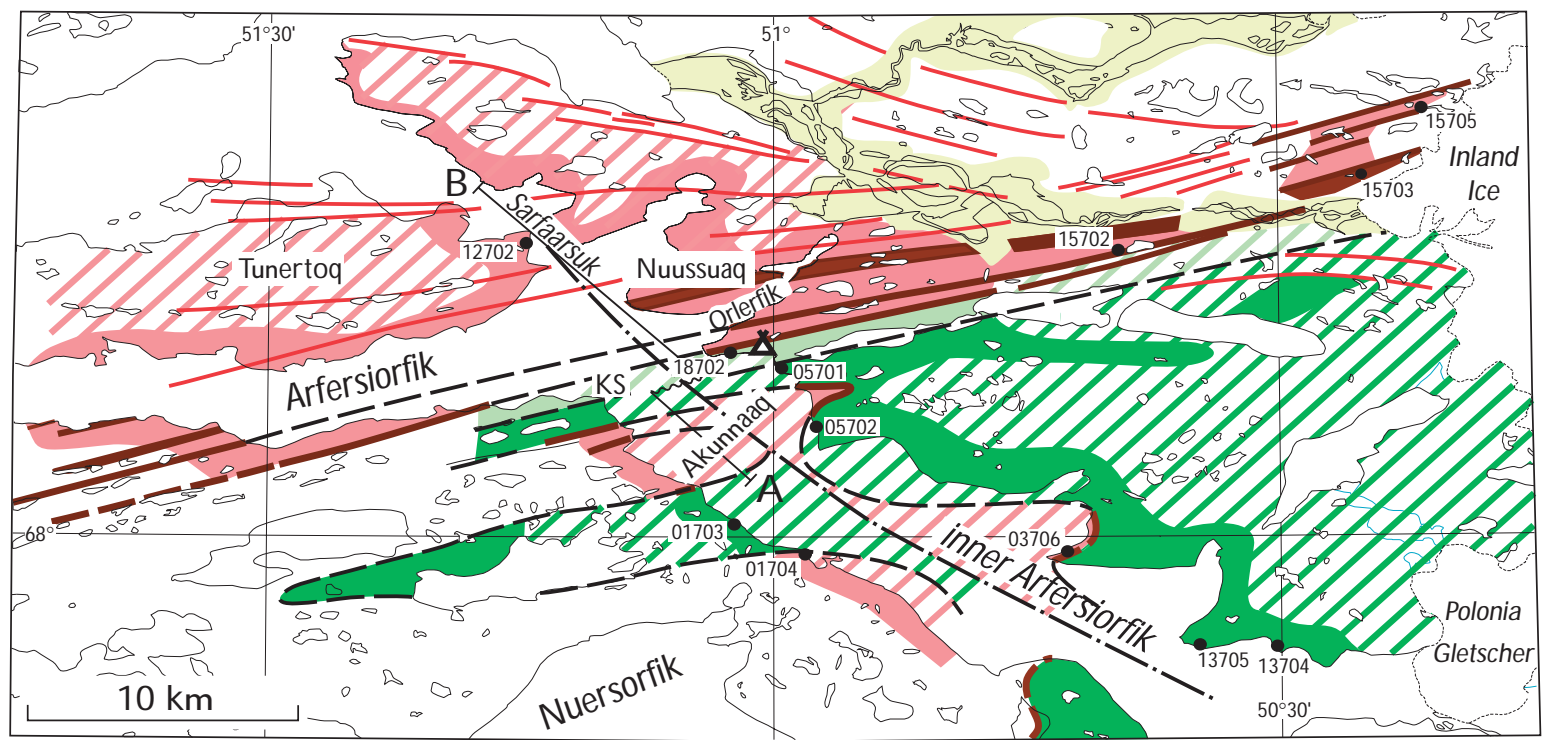

$\begin{aligned} & \text { Arfersiorfik Q uartz D iorite (AQD), } \\ & \text { mapped and inferred }\end{aligned}$
$\begin{aligned} & \text { Highly deformed, chemically altered and } \\ & \text { pegmatite-invaded part of the AQ D } \\ & \text { ('pencil gneiss'), mapped and inferred }\end{aligned}$

Fig. 2. Simplified geological map of the inner Arfersiorfik region, showing the authors' 2002 field work al ong full-coloured coasts (see also Fig. 1). Compare the mapped geology with the magnetic patterns on Fig. 7, shown at the same scale. Red lines, structural trend lines mainly from aeromagnetic data. KS, Kangimut Sammisoq (near map centre). Five digit numbers, locality numbers mentioned in the text. Two antiformal folds east of the inferred fault along inner Arfersiorfik are outlined by the AQ D contact overlying siliceous gneisses north of localities 05702 and 03706. The axial trace of the intervening synformal fold meets the coast near loc. 01703. Tent symbol, position of camp during 2002 field work. Inland geology near N uersorfik from van G ool \& M arker (2004).

thrust nature. Farther to the south, in the area between the heads of Nordre Strømfjord and Arfersiorfik, a thin (up to $500 \mathrm{~m}$ ) sheet of AQ D with tectonic contacts occurs with Archaean siliceous gneisses both above and below the AQD sheet (the Ussuit unit; Manatschal et al. 1998; van Gool et al. 1999). Thegeometry of this bounding surface is interpreted as outlining a series of folds. O nly the northern limb of the northernmost synformal structure is contained within the composite profile of Fig. 3. Folding of the AQD was observed by H enderson (1969) and later elaborated upon by Passchier et al. (1997) and van Gool et al. (1999). At the local ities outside the shear zone wherethe $A Q D$ can be seen in contact with thestructurally underlying siliceous gneisses (localities 01702,

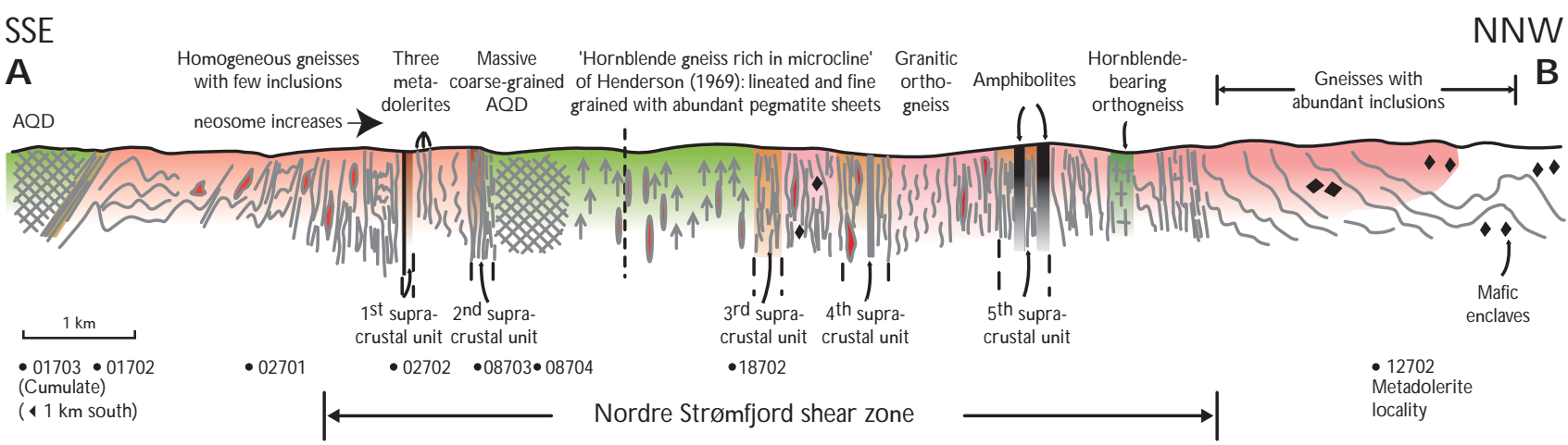

Fig. 3. Schematic profileA-B through the N ordreStrømfjord shear zone in theinner Arfersiorfik from A kunnaaq in the south to Sarfaarsuk in the north (Figs 2, 7). Localities and lithologies have been projected onto the profile plane along the strike direction of the shear zone. Locality numbers mentioned in the text appear beneath the profile. For colour code, consult caption to Fig. 2. 

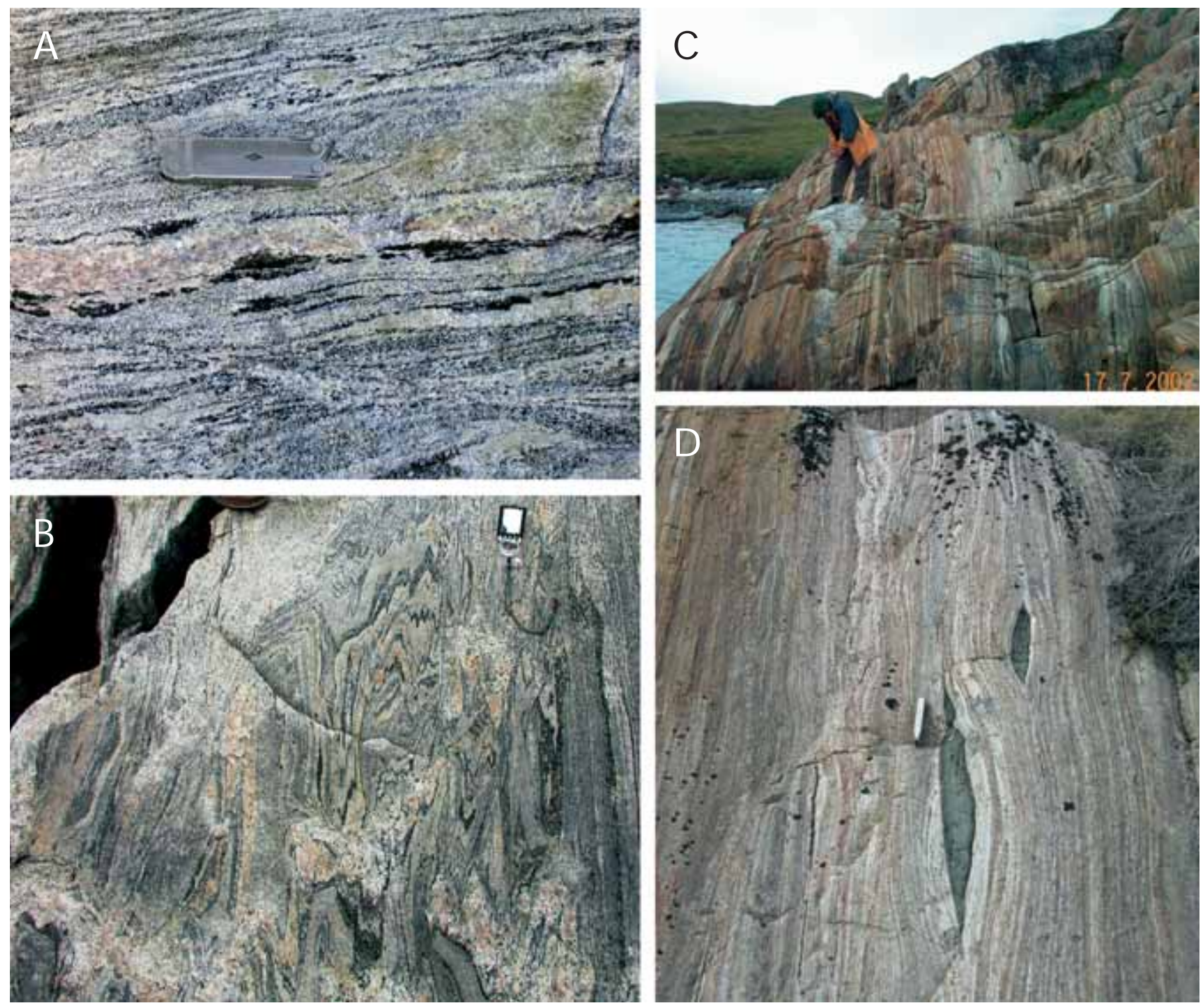

Fig. 4. Siliceous gneisses between localitiess 17701 and 02702 (Figs 2-3) illustrating progressive deformation towards the first supracrustal unit. A: C oarsely banded biotite gneiss, loc. 17701 (knife $10 \mathrm{~cm}$ long). B: Finely banded gneiss with generally steeply oriented foliation, but apparently variable deformation intensity at outcrop scale, loc. 02701 (compass $10 \mathrm{~cm}$ long). C: Extreme planar fabric and fine-scale layering in siliceous gneiss near the first supracrustal schist unit, loc. 02702. D : D etail from the same locality with lenticular ultramafic inclusions (knife $10 \mathrm{~cm}$ long).

01704, 03706, 05701, Figs 2, 3), the contacts are all tectonised, and with a well-developed, folded planar fabric. 0 riginal intrusive features have been obliterated except at loc. 05702 (Fig. 2), where xenoliths of pelitic schist can be seen within the $A Q D$, clearly indicating intrusion of the quartz dioriteinto a pre-existing metamorphosed sedimentary sequence.

From loc. 01702 (Fig. 3) and towards the north, siliceous gneisses become progressively more deformed and contain an increasing amount of granitic material. For a distance of almost $1 \mathrm{~km}$ to the south of the first supracrustal schist unit, the gneisses display a subvertical planar fabric and contain abundantlayersof leucocratic, in places pegmatitic, material. Thesegneisses appear highly strained. Thetransition within thesegneisses, from 01701 to 02702 (Fig. 3), is the best exposed transition zone developed in siliceousgneisses in the area that we have visited. Thestructural development of these gneisses is illustrated in Fig. $4 \mathrm{~A}-\mathrm{C}$.

Thefirst supracrustal unit (Fig. 3) comprises a predominant lithology of mafic schists with calc-silicate and ultramafic lenses. Pelitic schists are subordinate. At locality 08703, a second thin supracrustal unit of pelitic schist (thickness $25 \mathrm{~m}$ ) occurs along the boundary to the AQD . The gneisses to the north of the first supracrustal unit contain abundant layers of homogeneous amphibolite, 


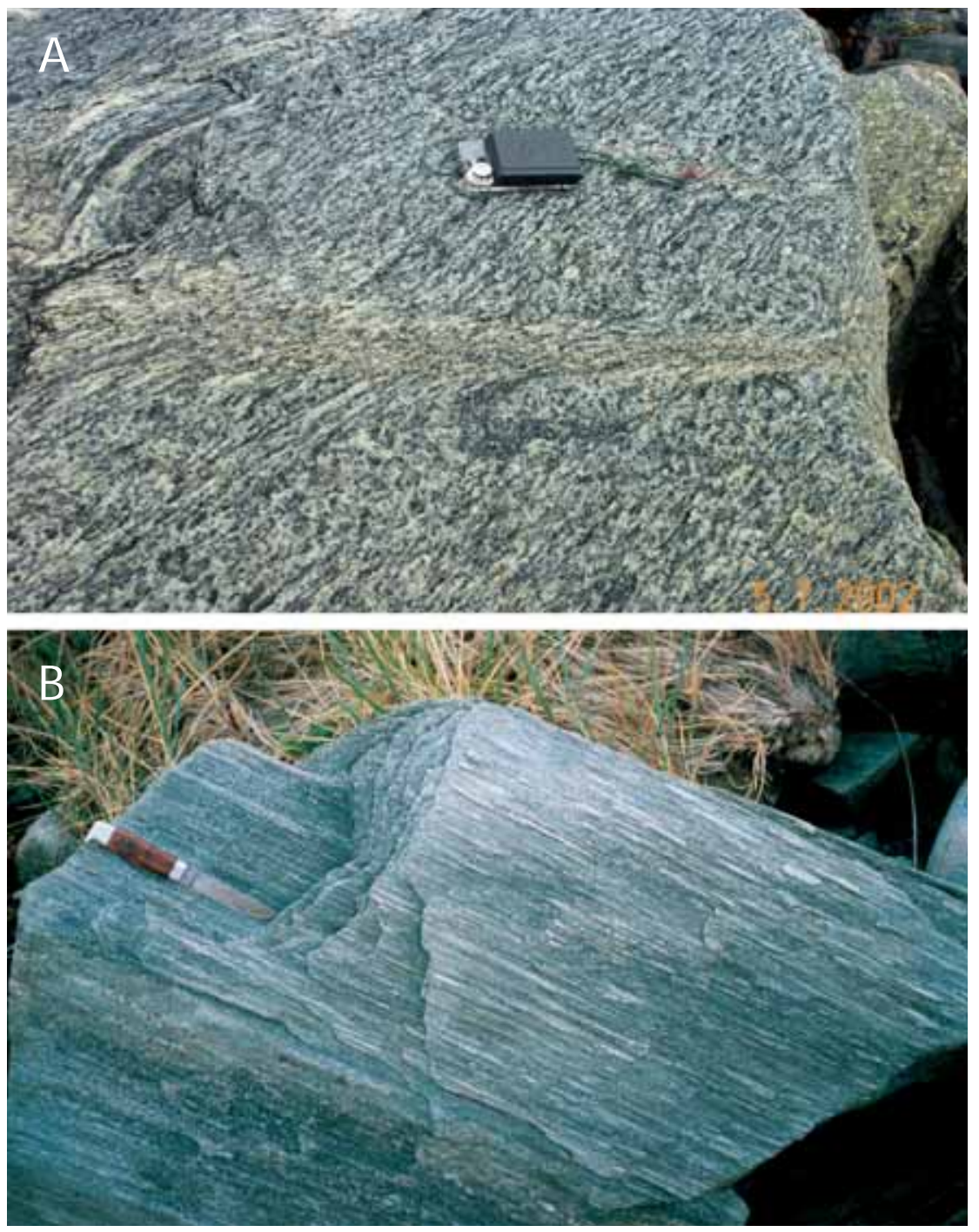

Fig. 5. Arfersiorfik quartz diorite. A: Coarsegrained metamorphosed quartz diorite with pervasive linear fabric. A minor dextral shear zone deforms the linear fabric (compass 10 cm long). B: Extreme linear fabric developed in $A Q D$ close to its northern boundary ('pencil gneiss'; knife $20 \mathrm{~cm}$ long).

with locally preserved discordant relationships to the host gneiss structures. These discordant amphibolites were undoubtedly originally dolerite dykes. Farther to the north, the gneissesarenearly devoid of amphibolites and are characterised by wavy and folded migmatitic structures without the pronounced planar fabric seen in the gneisses adjacent to the first supracrustal unit.

The contact between the second supracrustal unit and the AQD is vertical. C oarse-grained segregations of granitic pegmatite in the schist appear to be smeared out and pulled apart. The AQ D near this contact is syntectonically recrystallised and displays layering on a centimetrescale. The AQD farther to the north of the contact becomes relatively coarse grained and in places preserves undeformed magmatic structures (see a later section with more details on the petrology of the AQD). These relatively coarse-grained AQD rocks become progressively tectonised towards the north, developing a very pronounced L- tectonite fabric. Pegmatite sheets al so become abundant, and the $A Q D$ itself becomes progressively more leucocratic. $\mathrm{H}$ enderson (1969 p. 7) describes this transition with these words: "In the inner part of Arfersiorfik a zone of basic gneiss of a type not found elsewhere in the area was encountered. This is a hornblende gneiss rich in microcline. It contains numerous pegmatites", and further, "A large folded quartz diorite body dominates the inner part of Arfersiorfik ... O n its northern side it is in contact with the hornblende gneiss rich in microcline mentioned pre viously" (H enderson 1969, p. 11). Weinterpret the "hornblende gneiss rich in microcline" as the northernmost, most highly deformed (and most chemically altered) equivalent of the much less deformed and more igneous appearing $A Q D$ to the south of the shear zone. N evertheless, the $A Q D$ to the south of the shear zone is in most places also a tectonite; a mineral lineation is nearly al ways present in the rock. Textures viewed on sections perpen- 
Fig. 6. Pelitic and mafic schists from supracrustal unit near the I nland I ce visited during helicopter reconnaissance, loc. 15705 (Fig. 2). A: Two-mica sillimanite schist with abundant 'winged' feldspar blasts indicating sinistral sense of shear. Long dimension of photo c. $75 \mathrm{~cm}$. B: Amphibolitic schist with boudins of garnet-bearing ultramafic rock (hammer c. $50 \mathrm{~cm}$ long).
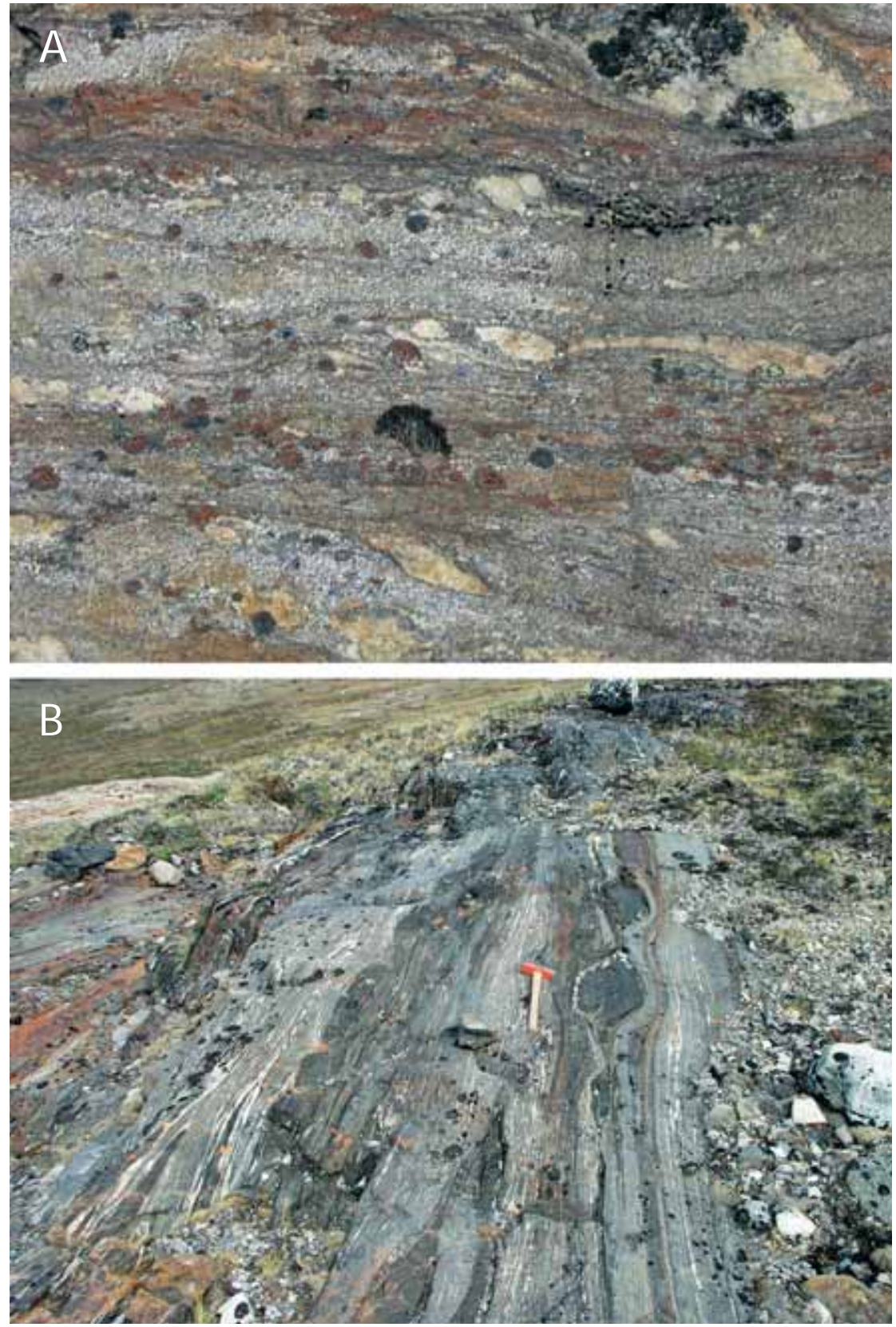

dicular to thelineation appear igneous, whilea pronounced tectonic lineation is seen in other orientations (Fig. 5). The transition from the more magmatic appearing $A Q D$ to the "hornblende gneiss rich in microcline" is gradual, and the continuity of these rocks is evident on either side of Arfersiorfik.

Between the third and fourth supracrustal units siliceous gneisses of varying heterogeneity and apparent degree of shear zone deformation occur, all with a vertical planar structure. Basic inclusions are common in this gneiss unit.

The fourth supracrustal unit as exposed on the eastern shore of O rlerfik is a lithologically variable assemblage of pelitic schists and gneisses, amphibolitic schists, and calcsilicate gneiss. 0 verall, the rocks appear highly deformed. The pelitic rocks typically contain numerous layers and lenses of pegmatitic material up to $8 \mathrm{~m}$ thick. Cordierite was observed in the schists, and a lens of tourmalinite was also found. N ear thel nland I ce, at loc. 15703(Fig. 2), a centimetre-thick marblelayer, the only occurrence of marble seen during field work, was observed in a pelitic schist thought to be the merged equivalent of the third and fourth supracrustal units at O rlerfik.

The gneisses between the fourth and fifth supracrustal 
units are quartzofeldspathic. A rather homogeneous, granitic orthogneiss $1 \mathrm{~km}$ wide occurs immediately to the north of the fourth supracrustal unit. It contains a few mafic inclusions which appear to be metadolerites. This gneiss, although foliated, has not developed the typical shear zone fine layering, and it is clearly an orthogneiss. Towards the north, quartzofeldspathic gneisses with numerousgraniticlayersand bandsform theboundarytowards the fifth supracrustal unit. The finely banded shear zone planar structure is developed in places. The gneisses between the fourth and fifth supracrustal unit thus appear to be progressively deformed towards the north.

The fifth supracrustal unit is well exposed at 0 rlerfik and along the western shore of the N uussuaq peninsula. On N uussuaq, this unit forms an elongateridge of strongly rusty weathering rocks. In fresh exposures in thetidal zone, the rusty weathering rock can be seen to be a fine-grained graphite- and sulphide-bearing darkish grey gneiss. In this unit, finely banded amphibolitic schists are prominent, along with pelitic sillimanite-bearing schists. C alc-silicate rocks are seen as well, as also described by $\mathrm{H}$ enderson (1969). Pegmatitic layers are abundant. We were unable to confirm the marble layer occurring on the western half of the N uussuaq peninsula on H enderson's (1969) map. We found, instead, a complex of light-coloured, in some places greenish, anthophyllite-phlogopite-diopside-bearing metamorphosed ultramafic rocks.

It appears that all the supracrustal units, although structurally continuous, change lithologically along strike, consisting of various combinations of pelitic schists and gneisses, graphite-sulphide gneisses, calc-silicate rocks, mafic schists and ultramafic lenses. In all the supracrustal units deformation appears to beintense. Both pelitic and mafic rocks are finely schistose (Fig. 6). Ultramafic and skarn lenses may be rather massive and homogeneous, but they are small in size and volumetrically minor. 0 verall, the supracrustal units are schistose throughout, and differ in this way from the intervening siliceous gneisses, which are heterogeneously deformed on a $100 \mathrm{~m}$ scale.

To the north of the fifth supracrustal unit only scattered exposures of gneiss are found at O rlerfik. Along several localities near the northern boundary of the shear zone, at $O$ rlerfik and along the south coast of Tunertoq, a homogeneous, hornblende-bearing orthogneiss is encountered. In places it is reminiscent of the AQ D. Farther north of the shear zone in the area around Sarfaarsuk, gneisses with a complex history occur, as indicated by several generations of granitic and pegmatitic veins and layers, and mafic and ultramafic layers and lenses. At locality 12702 (Fig. 2), a number of mafic layers are clearly folded metadolerites, and at this locality it can be seen how new layer- ing develops concomitantly with deformation. Along this layering thethin metadolerites can be seen to be displaced, and it seems evident that new layering develops in the siliceous gneisses at small angles to the older layering. W ithout the metadolerites it would be impossible to discriminate between new and old layering.

\section{Aeromagnetic data}

The entire N ordre Strømfjord shear zone and adjacent areas are covered by regional aeromagnetic data (Figs 1B, 7) acquired during the project Aeromag 1999 (see text to Fig. 1B and Rasmussen \& van Gool 2000). The aeromagnetic map proved very useful for delineation of lithologies and structures in the field, and in general there is a very clear correlation between observed surface geology and the aeromagnetic anomaly patterns.

The Arfersiorfik quartz dioriteis associated with a variable magnetic signature. The best exposed part of the AQ D is located in inner Arfersiorfik just north of Polonia G letscher (Fig. 7). This part is denoted the core zone of the AQD complex and is characterised by a distinct positive anomaly (300-490 nT ). H ere an unusually large amount of magnetite was found, both as millimetre-scale magnetite needles and as magnetite grains $1-3 \mathrm{~cm}$ large. A pronounced decrease in the magnetic intensity of the $A Q D$ is observed just north-west of the core zone. The magnetic signature of the $A Q D$ changes towards the shear zone, where the fine-grained, pegmatite-bearing and strongly linear AQD (the 'pencil gneiss') that forms the northernmost 1-2 km of the body exhibits strong negative anomalies. These changes in magnetic signature appear to reflect metamorphic and metasomatic processes associated with the shear zone development. The demagnetising effects reflect the formation of titanite and biotite at the expense of FeTi-oxides, which is synchronous with shear zone evolution. D etailed thin section observations show that the modal abundances of titanite and magnetite/ilmenite are strongly negatively correlated. Comparison of titanite-rich samples and magnetite/ilmenite-rich samples with the vertical gradient of the magnetic anomaly field (obtained from the map shown in Fig. 7) shows that the titanite-rich samples consistently occur within negative changes in thegradient, while themagnetite/ilmeniterich samples occur within positive gradients. Further work is underway to evaluate the reliability of this correlation.

In general, the supracrustal schist units are associated with negative anomalies in the total magnetic field intensity. W ithin the shear zone, the schist units are characterised by pronounced, linear short-wavelength negative ano- 


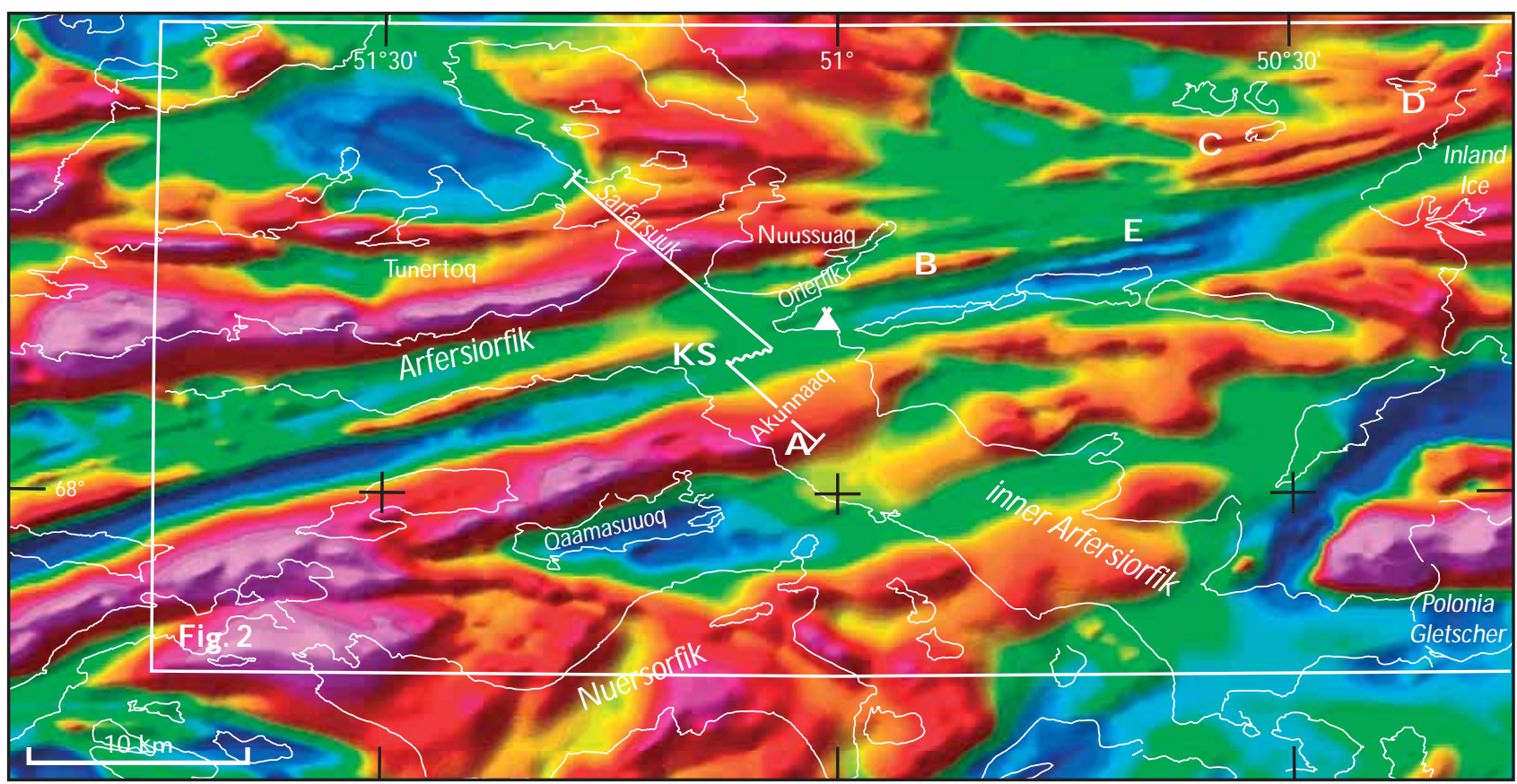

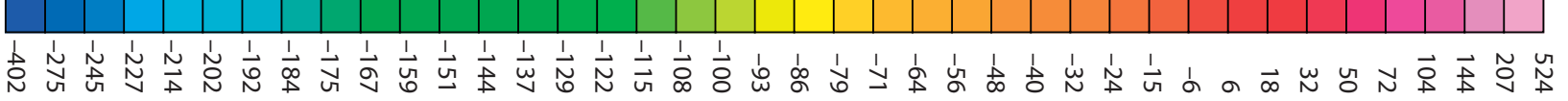

Fig. 7. Total magnetic field intensity map of the study area. A, Akunnaaq; KS, Kangimut Sammisoq; B, magnetic high coinciding with the orthogneisses between the fourth and fifth supracrustal units; C - D , lithological boundary between siliceous gneisses and supracrustal schists; $\mathbf{E}$, possible magnetic expression of merged fourth and fifth supracrustal units. The position of the camp site used during the field work is shown with a tent symbol. Compare the magnetic patterns with the mapped geology on Fig. 2 (white frame), shown at the same scale. $\mathbf{n T}$ : nanotesla, a unit of magnetic flux density.

malies (-150 to $-300 \mathrm{nT}$ ). At Kangimut Sammisoq (KS on Fig. 7) and towards the west-south-west the AQD and juxtaposed schists form a coherent negative anomaly, which can be traced for a considerable distance towards west-south-west into the Agto map sheet area (O lesen 1984). Within the latter area the anomaly reflects supracrustal rocks only. The negative anomalies of the supracrustal schists probably reflect the absence of Fe-Ti oxides and the abundance of iron sulphides and graphite, which yields a weak magnetic response.

In general, gneiss lithologies in the area are expressed as positive magnetic anomalies. Because of their greater volume, the gneisses are associated with broader wavelength anomalies than the supracrustal units. However, the shape of the anomalies associated with the gneiss units within the shear zone are of short wavelength and elongate (Fig. 7). Where a significant strain gradient in the siliceous gneisses is observed, e.g. northwards from Akunnaaq along the western shore of inner Arfersiorfik (from loc. 01702 to 02702 , Fig. 3), this transition is not visible in the magnetic field (A on Fig. 7). In general, it appears that even large changes in strain adjacent to and within the shear zone do not have a clear magnetic signature in the siliceous gneisses. While the magnetic lows associated with supracrustal units are in general persistent along strike, the highs associated with the siliceous gneisses in places outline lenticular structures, the most obvious example being the magnetic high which can be seen to coincidewith theorthogneisses between the fourth and fifth unit (B on Fig. 7).

\section{The general map structure}

Although we havenot carried out regional mapping, some map scale observations follow from our work. From the Inland Ice and for a distance of at least $35 \mathrm{~km}$ towards the south-west (i.e. in thearea between the Inland Ice and the bend of Arfersiorfik towards south-east west of $\mathrm{N}$ uussuaq), the AQD is bounded to the north by the shear zone, and probably with a continuous screen of supracrustal schists along its northern boundary. Towards this bounding schist, the AQ D becomes progressively deformed, developing a pronounced linear fabric and undergoing a number of 
mineral ogical changes, described below. These mineralogical changes are reflected in a change in magnetic signature. The change is less dramatic to the east of Arfersiorfik than it is to the west of the fjord, and this signature can be followed from the fjord to the Inland Ice and beneath the ice for at least another $30 \mathrm{~km}$. Based on aeromagnetic data covering the entire $G$ reenland including the Inland I ce, N ielsen (2004) and N ielsen \& Rasmussen (2004) suggest a $125 \mathrm{~km}$ eastward extension of the AQ D ben eath the ice.

The outcrop pattern and orientations of the boundary between the AQ D and the structurally underlying schists and gneisses are in accord with a structural model involving relatively open folding, as marked on Fig. 2. $0 \mathrm{n} \mathrm{H}$ enderson's (1969) map, a tongue' of siliceous gneisses projects from the eastern shore of the fjord $20 \mathrm{~km}$ eastwards into the AQD . D uring helicopter reconnaissance by us, this eastward-reaching gneiss was nowhere to be seen. Along the shores of Arfersiorfik, there is an antiformal closure of $A Q D$ over siliceous gneisses with an intervening schist screen, but this cannot extend inland for morethan $2 \mathrm{~km}$. The entire triangular area bounded by Arfersiorfik, the shear zone, and the Inland Ice is most likely only underlain by AQ D. T he map pattern west of inner Arfersiorfik differs from the pattern described above. Along the shoreline south of Kangimut Sammisoq the southern boundary of the AQD is vertical, and south of the boundary, gneisses and the schists of the first supracrustal unit are also vertically oriented and possess a well-developed planar shear zone fabric. We interpret this difference in map pattern as reflecting intersections with the shear zone boundary at two different levels.

\section{Petrology}

\section{Arfersiorfik quartz diorite}

The Arfersiorfik quartz diorite was first mapped in the study area by Henderson (1969), who noted that it varies from a homogeneous, coarse-grained igneous rock in its central region which lacks evidence of deformation, to a compositionally banded gneiss near its margins. Further work by K alsbeek et al. (1984, 1987) and K alsbeek (2001) supported the general descriptions of $\mathrm{H}$ enderson and provided a considerable body of evidence regarding the age and chemical composition of the body. O ur observations expand on these earlier results.

W ithin the 'greater AQD igneous complex' we have observed a number of lithologies indicative of a complex igneous history (Fig. 8). At loc. 01703 (Fig. 2) we ob- served a locally developed layered cumulate sequence(Fig. $8 \mathrm{~A}$ ) in gradational igneous contact with quartz diorite that contains blocks of more mafic igneous rocks. The cumulate sequence consists of numerous cycles of pyroxene-olivine cumulate layers grading into plagioclase-pyroxene anorthositic layers. T his rhythmic layering grades upward into massive dioritic and quartz-dioritic rocks that contain plagioclase-porphyritic mafic xenoliths. At the same structural level, but farther north at loc. 08704, mafic enclaves (Fig. 8B) occur within leucocratic quartz diorite. In places, these enclaves contain plagioclase-porphyritic xenoliths similar to those observed at loc. 01703. We interpret these enclaves to be evidence of mixing of magmas, similar to that reported for other igneous bodies (e.g. Gagnevin et al. 2004; H ealy et al. 2004; Janousek et al. 2004). The presence of both cumulate rocks and mixed mafic magmas at approximately the same structural level suggests that these sites represent the lower levels of the igneous complex that makes up the AQD suite.

At loc. 13705 clear evidence of at least two separate magmas in an undeformed state is preserved, with a later diorite exhibiting well-developed chilled margins against an earlier quartz diorite (Fig. 8D ). W hether this implies that the AQD is actually a collection of numerous smaller intrusions or a major igneous body with local, small and rare later intrusive phases can only be resolved with more detailed field work. At loc. 18702 (Fig. 2) we have also observed a finely banded rock, apparently developed by extreme deformation of a sequence of pillow lavas (Fig. 8D ). This latter occurrence was found close to the northern boundary of the $A Q D$ and may represent the upper part of the 'greater AQD igneous complex'. W ithin the thin sheet of $A Q D$ to the south of the localities that we examined, an occurrence of metavolcanic rocks was reported by $M$ anatschal et al. (1998), which supports the interpretation that exposures of the AQD suite represent a variety of deep to near-surface original positions.

In thin section, the mineralogy of the AQD suite is invariably modified by metamorphic recrystallisation. Textural features suggest that the AQD originally consisted of hornblende and pyroxene diorites and quartz diorites. In those rocks with primary pyroxenes, the ortho- and clinopyroxenes are partial ly to completely recrystallised to intergrowths of plagioclase, hornblende, quartz, magnetite, ilmenite and sometimes biotite. In instances where the pyroxene is completely replaced by amphibole, the amphibole is densely filled with inclusions of magnetite/ ilmenite. In the hornblende diorites and quartz diorites the original igneous amphiboles are generally inclusionfree and tend to have more brownish pleochroic colours. In some cases, plagioclase crystals exhibit well-preserved 

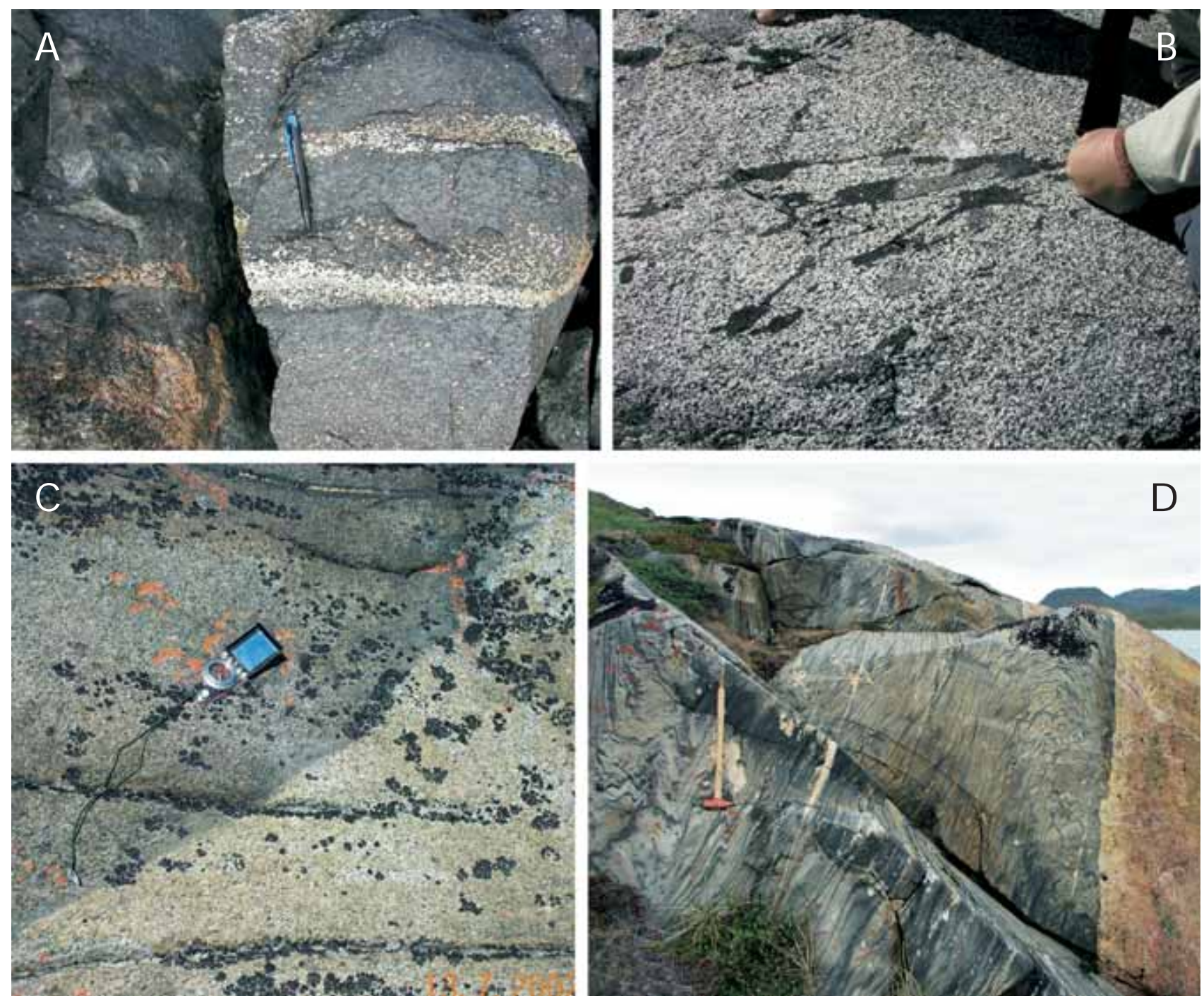

Fig. 8. Extent of lithological variation within the 'greater Arfersiorfik quartz diorite complex'. A: I gneous layering at loc. 01703 (Fig. 2), where an assemblage of undeformed cumulates and related rocks from the AQ D suite is set in a host of tectonised (lineated) AQD (pencil c. $15 \mathrm{~cm}$ long). B: Igneous textured AQD with hornblende-rich pods indicating fractionation or magma mingling. O bserve light grey xenolith within hornblende rich phase immediately north-east of centre of photo (fist for scale). C: D ark coloured igneous rock (left) chilling against lighter coloured rock (right), loc. 13705 (Fig. 2; compass $10 \mathrm{~cm}$ long). D : Part of a pegmatite sheet (right) within a banded amphibolitic rock (left) interpreted as strongly deformed pillow lava (hammer handle c. $50 \mathrm{~cm}$ long).

igneous oscillatory zoning, but usually this is partially to completely replaced by metamorphic zoning. Cummingtonite-hornblendeintergrowths are relatively common and are identical to similar features described from dioritic rocks affected by amphibolite facies metamorphism in other parts of the world, e.g., Tanzania (H aslam \& Walker 1971), U SA (N ew H ampshire, Brady 1974; the G rand Canyon, Clark 1978), and Australia (N ew South Wales, Stephensen \& H ensel 1979). Recrystallisation of theAQ D occurred within middle to upper amphibolite facies, as indicated by the hornblende-biotite-plagioclase \pm garnet association, the instability of ortho- and clinopyroxene with amphibole, and the development of cummingtonitehornblende intergrowths.

The chemical variability of the AQD suite (Fig. 9) is typical of that of other calc-alkaline igneous complexes, as noted previously by Kalsbeek et al. (1987) and Kalsbeek (2001) who demonstrated si milarities between these rocks and the Sierra Nevada batholith. Including their data, we have expanded the comparison to that of the C ascades of Washington State, U SA, the M $t$ Lassen complex of California, and the southwest Pacific island arc 


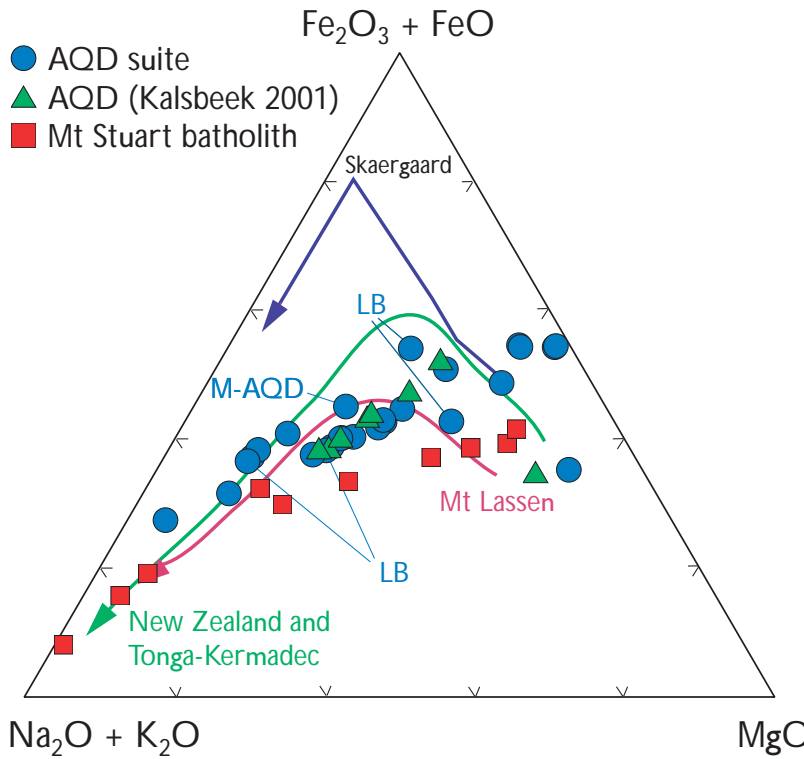

Fig. 9. AFM diagram comparing Arfersiorfik quartz diorite chemistry (including the large boulder samples labelled 'LB') to that of other calc-alkaline systems. The trend for the Skaergaard igneous complex is shown for comparison. M t Stuart data from Erikson (1977). All other trends from Best (1982). The sample labelled M - AQD is the mylonitised quartz diorite sample mentioned in the text.

system. The compositional range of the AQ D suiteis large, varying from ultramafic (within the cumulate complex) to quartz-dioritic and quartz-monzonitic. The compositional evolution of the magma appears to have been controlled by crystal fractionation of olivineand/or pyroxenes when the cumulates were forming, but eventually reaching the stage where hornblende fractionation dominated the chemical evolution of the magma (Fig. 10). The one samplethat deviates from thesetrends is labelled $M-A Q D$. This is a fine-grained biotite-plagioclase-quartz mylonite produced by local granulation of coarse grained $A Q D$. Further study of this sample is underway to understand the controls on this alteration process.

Wenoted that in the near vicinity of the N ordre Strømfjord shear zone chemical modification of the AQD appears to be significant. Development of K-feldspar-rich mineral assemblages is common, and often accompanied by the association calcite-titanite. These rocks occur in the same region in which Henderson (1969) noted the presence of $\mathrm{K}$-feldspar-rich gneisses. The magnitude, extent and significance of these chemically unusual rocks are under investigation. M etasomatism at the AQ D margin and minor shear zones within the AQD were described by Kalsbeek et al. (1987).

Included in Figs 9, 10 are four analyses (labelled LB) from samples of large boulders in outwash from glacial

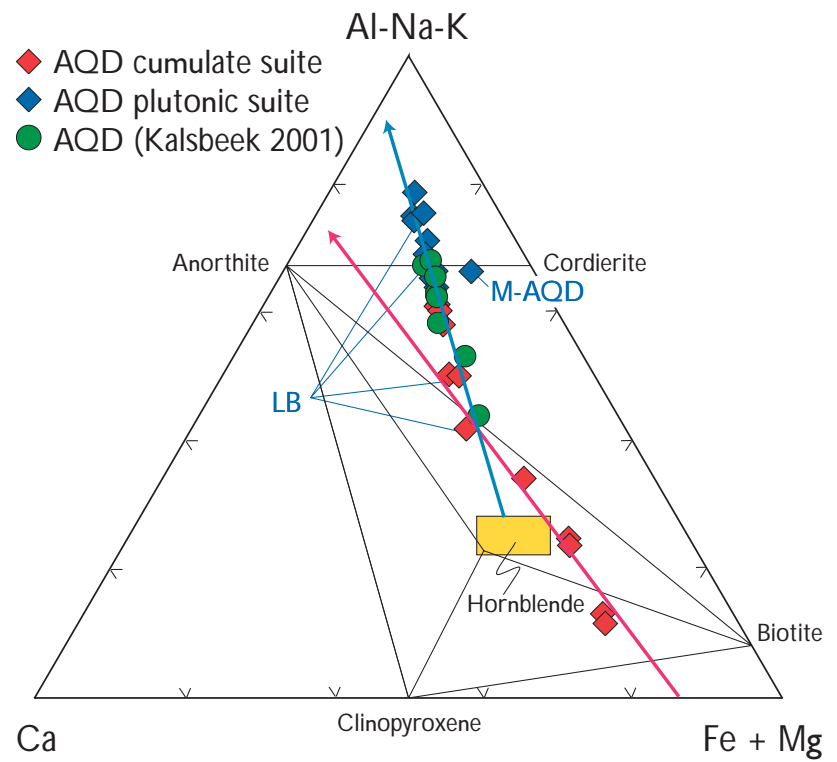

Fig. 10. ACF atomic triangular diagram showing the chemical variation in the Arfersiorfik quartz diorite based on our data (including the boulder samples L B and data reported by Kalsbeek 2001). Red symbols, samples collected within cumulatelocal ities. Blue and green symbols, collected by us and K al sbeek (respectively) from the non-layered igneous complex. $\mathrm{N}$ ote the kink in the trend of chemical evolution and the overlap between the non-layered and cumulate rocks of the Arfersiorfik quartz diorite. Red arrowed line, the trend of magmatic evolution implied by the cumulate samples, reflecting fractionation of some combination of olivine and/or orthopyroxene with clinopyroxenein the most primitive cumulate suite. Blue arrowed line, that suite of samples for which chemical variability can be ascribed to hornblende fractionation. Yellow box: outline of the range of likely hornblende compositions. M-AQ D, mylonitised quartz diorite sample mentioned in the text.

deposits, collected several hundred metres east of our camp (see Fig. 2). In the field, the samples bear striking similarity to $A Q D$ lithologies. As is evident from the figures, these rocks are chemically indistinguishable from the $A Q D$ suite, supporting evidence from aeromagnetic data discussed above that the A Q D extends under the icefor some distance.

\section{Late garnet granite}

The southernmost samples collected (loc. 13704, Fig. 2) are from a site at which peraluminous garnet granite exhibits classic intrusive relationships into granodioritic to quartz-dioritic gneisses of the AQ D. This granite contains stoped blocks of gneisses within the upper $30 \mathrm{~m}$ of its upper boundary zone (Fig. 11), and dykes and sills from the granite invade the gneiss. The granite itself contains 


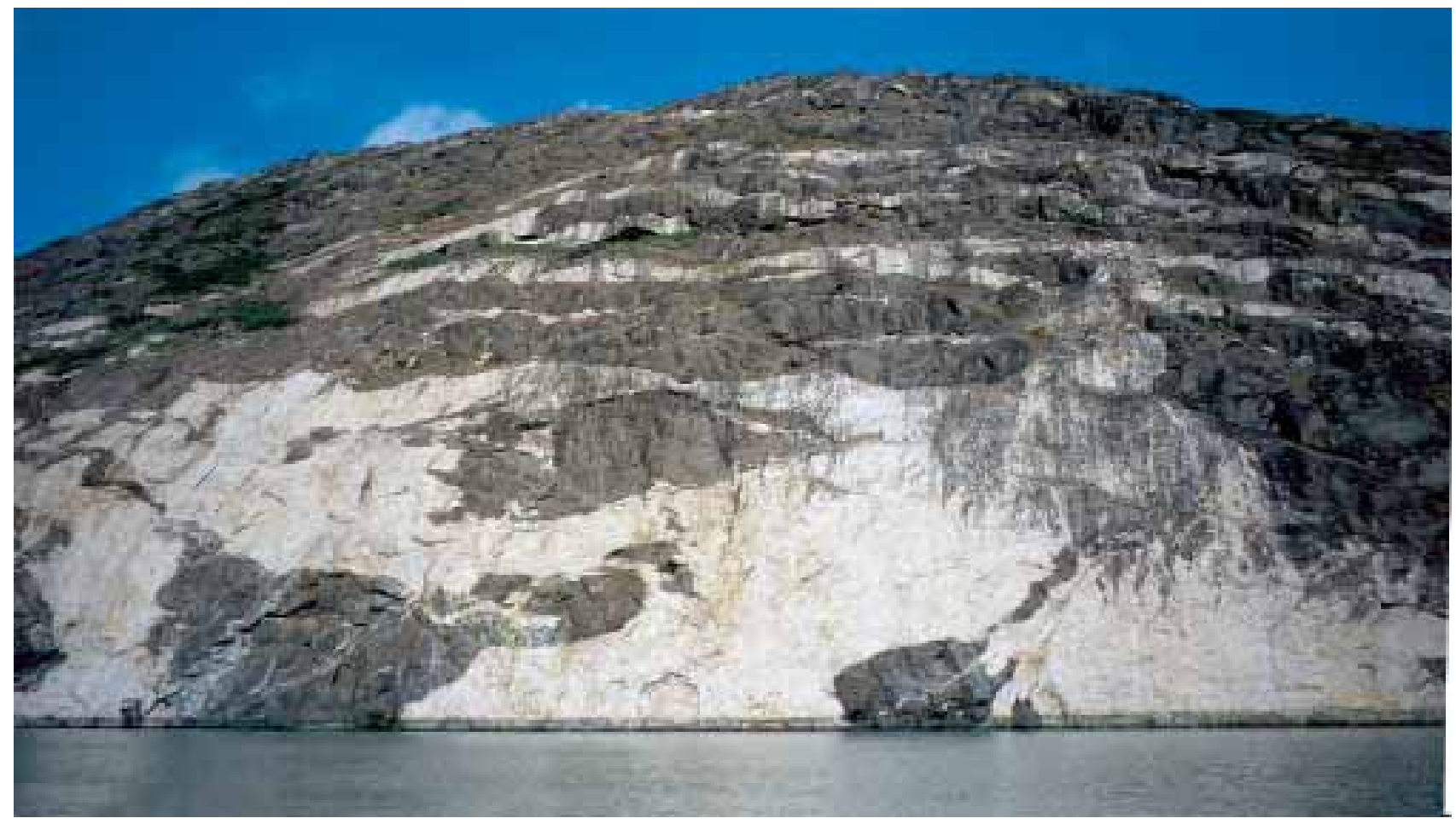

Fig. 11. Peraluminous garnet- and muscovite-bearing granite at loc. 13704 (Fig. 2) intruding into Arfersiorfik quartz diorite and interpreted as the roof zone of a pluton with rafts of country rock and sheets of granite above. Looking north-north-east. H eight of section c. $150 \mathrm{~m}$.

delicate, primary muscovite rosettes and myrmekitic intergrowths with no evidence of deformation. The intrusive relationships and the preservation of delicate primary igneous structures suggest that the granite invaded postkinematically, and that it could provide excellent samples for establishing a minimum age for the time of cessation of tectonic activity in the region.

\section{Late stage, low-grade metamorphism}

A suite of samples from the $A Q D$ in the region south of the N ordre Strømfjord shear zone contain postkinematic mineral assemblages of the prehnite-pumpellyiteand lower greenschist facies overprinting the higher grade metamorphic mineral assemblages that definetheamphibolitefacies metamorphism. T his late-stage, low-grade metamorphism is associated with brittle fracturing and veining, and local piemontite and base metal mineralisation. The timing of this low-grade metamorphism remains unresolved.

\section{Strain variation within the Nordre Strømfjord shear zone}

Earlier work within the Agto map sheet (Fig. 1; Bak et al. 1975b; Sørensen 1983) concluded that the Nordre Strømfjord shear zone reflects sinistral transcurrent movement. It wasal so concluded from thefanning of planar structures that the shear zone is wedge-shaped within the Agto map sheet. The present work has shown that in the inner part of Arfersiorfik such fanning is not obvious, perhaps because the zone here is only half as wide as near the coast in the Agto map sheet area. The planar structures within the shear zone are vertical (Fig. 3) with an extremely limited variation of dips (Fig. 12), and linear structures are horizontal. The justification for drawing the schematic profile(Fig. 3) with vertical lithological boundaries throughout the shear zone is evident from the stereograms of Fig. 12.

The horizontal orientation of linear structures is also in accordance with a horizontal movement direction and with the orientation of linear structures in the western part of the shear zone (Bak et al. 1975b). The sinistral shear sense, already inferred by Bak et al. (1975b) and further discussed and analysed by Sørensen (1983), is obvious from the large-scale anticlockwise rotation seen in 


\section{Planar structures Linear structures}
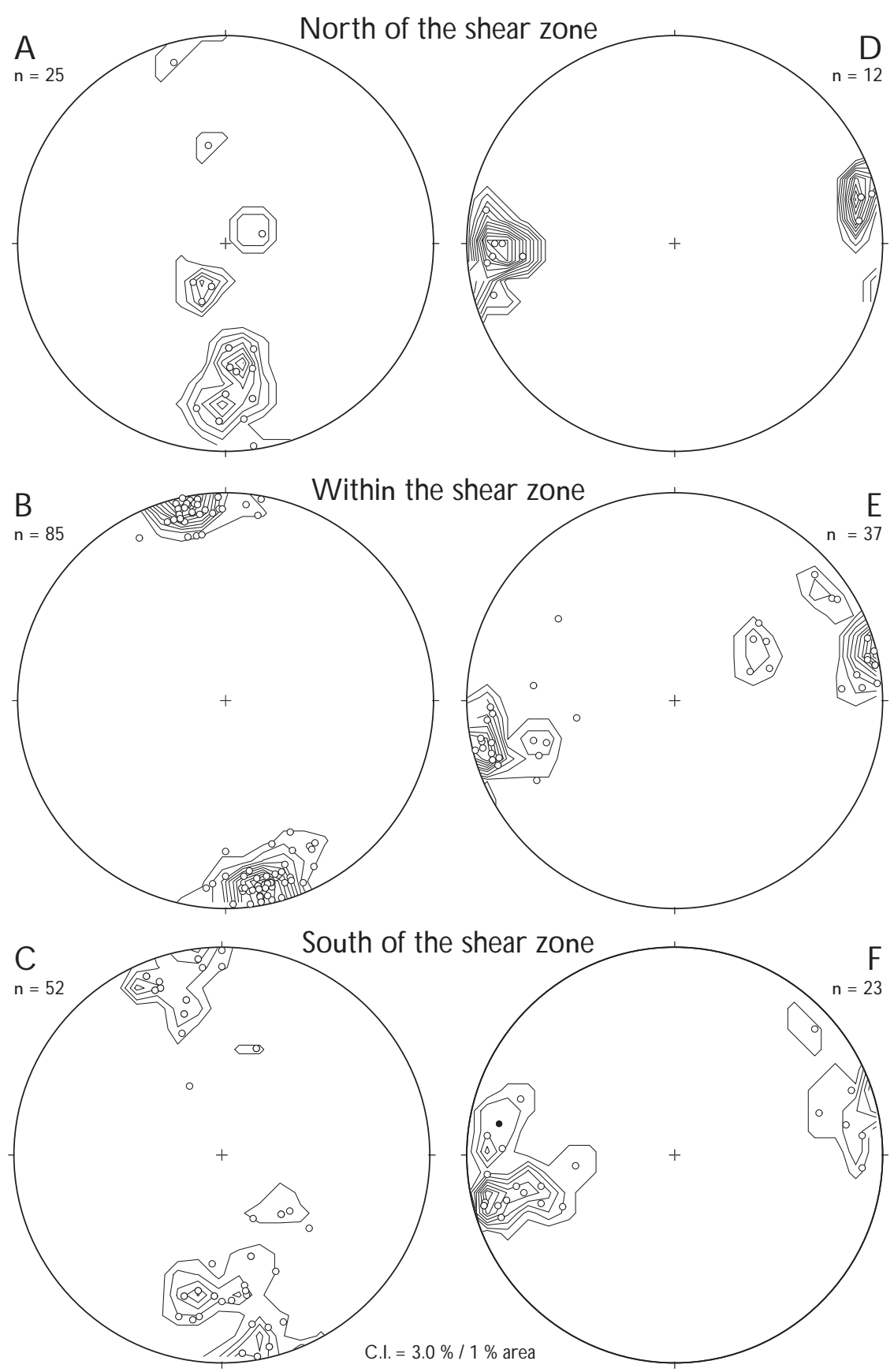

Fig. 12. Stereograms of planar and linear structures from within and outside the N ordre Strømfjord shear zone. While linear structures (D - F) outside and within the shear zone do not differ in orientation, planar structures $(\mathbf{A}-\mathbf{C})$ within the shear zone are seen to be extremely concentrated as opposed to the wider spread of planar structures al ong girdles perpendicular to the linear structures outside the zone. Equal area lower hemisphere projections. Contour interval $=3 \%$ of plotted points per $1 \%$ of stereogram area. the aeromagnetic data (Figs 1, 7). Small-scale shear sense indicators confirm this pattern (Fig. 6). They do not occur abundantly, and as the large-scale features of the entire shear zone from the coast to the Inland Ice leave no doubt about the sinistral nature of movement, we have madeno systematic investigations of small-scale shear sense indicators.

It was suggested by Sørensen (1983, fig. 14) that the shear zone between Arfersiorfik and the Inland Ice could be divided into an central part bounded by two marginal zones. H efurthermore speculated (p. 3432) that the strain profile at the Inland I ce was suggestive of superposition of two mechanisms, one responsible for most of the deformation in the marginal zones, and another responsible for the major part of the strain in the central part of the shear zone. The rotation on which this suggestion was based is also evident, for example, on the aeromagnetic data between labels $C$ and $D$ on Fig. 7, and from there 
farther towards thewest-south-west. 0 ur field work demonstrates that this line is in fact a lithological boundary between siliceous gneisses and supracrustal schists. A corresponding boundary may be placed at the boundary between the 'pencil type' AQD and the schist that wehave termed the third supracrustal unit on Fig. 3, and thus like the northern line of rotation coincides with a lithological boundary. T hroughout the shear zone all the supracrustal units are highly and penetratively deformed, whereas the intervening orthogneisses are heterogeneously deformed. Furthermore, where visited by the authors, theboundaries to the central part of the shear zone do in fact correspond to lithological boundaries involving supracrustal schists. In addition, the intervening siliceous gneisses, as judged from the aeromagnetic map, may in places form augenlike features, as for example, immediately north of $E$ on Fig. 7. T he eastern tip of this positive magnetic anomaly was visited by helicopter (loc. 15702). Immediately east of this locality the fourth and fifth supracrustal units can be seen to be separated by a few tens of metres of siliceous gneiss, a unit which is almost $2 \mathrm{~km}$ wide along 0 rlerfik $15 \mathrm{~km}$ to the west. To the east of this locality, a wide negative magnetic anomaly can be seen to underlieunexposed ground (E on Fig. 7). We interpret this as the magnetic expression of the merged supracrustal unitsfour and five. O ur work in Arfersiorfik therefore suggests a model for strain variation that is fundamentally different from the model developed by Sørensen (1983) for the western, lower crustal and most high-grade part of the shear zone. Where the latter model suggests continuity of lithologies from wall to wall of the shear zone, our observations in Arfersiorfik indicate that adiscontinuitiesy in strain may be associated with boundaries between schists and orthogneisses. It is furthermore suggested by the aeromagnetic data that theintervening siliceous gneisses may form augen-like features. The change in deformation mechanism suggested by Sørensen (1983) may therefore reflect ductility contrasts between the supracrustal schist units and the siliceous gneisses and not the superposition of two different deformation mechanisms.

\section{Mineral occurrences}

Two dominating types of mineral occurrences have been found in the inner part of Arfersiorfik: (1) occurrences of disseminated to massive pyrrhotite in supracrustal mica schist units and (2) occurrences of iron sulphides in the contact/fault zones between the AQD and juxtaposed supracrustal units. The former type is associated with strongly foliated amphibolite, biotite \pm graphite \pm sillima- nite schist and paragneiss. The pyrrhotite is found either as horizons up to $0.5 \mathrm{~m}$ thick or as lenticular bodies or pods up to $1 \times 2 \mathrm{~m}$ in outcrop size. This type of occurrence is only found in the supracrustal rock units within the shear zone. Similar occurrences exist west of theinvestigated area all the way to the outer coast just north of the mouth of N ordreStrømfjord. This occurrencetypeisinterpreted as syn-genetic volcanic-associated exhalative sulphide deposited in a volcanic arc environment. The highest analytical values of gold and base metals obtained from samples of disseminated sulphides in pelitic schist are the following figures: 38 ppb Au, 45 ppm As, 497 ppm Zn, 3813 ppm Cu and 456 ppm N i. All samples have elevated $\mathrm{M} \mathrm{n}$ concentrations, up to $2.9 \mathrm{wt} \% \mathrm{Mn}$. The second type of mineral occurrence is widespread in theinner part of Arfersiorfik, both within and outside the shear zone. Thezones hosting the sulphides are often associated with alteration, and in many cases a high degree of silicification is observed. It is unknown if this type is strictly epigenetic, caused by hydrothermal activity along the contact or in the fault zones between the AQD and the minor supracrustal units, or if it is a product of hydrothermal remobilisation of syngenetic iron sulphides in the supracrustal rock units. For more details and description of mineral occurrences in central West Greenland see Steenfelt et al. (2004) and Stendal et al. (2004).

\section{Conclusions}

O ur investigations of the N ordre Strømfjord shear zone in the eastern part of Arfersiorfik suggest that deformation and displacement at this crustal level are primarily a function of lithology, with large displacements effected by ductile flow in the supracrustal sequences. The large mass of Arfersiorfik quartz diorite between Arfersiorfik and the Inland Ice is bordered to the north by the shear zone, probably with a supracrustal schist unit along this boundary. The latter is indicative of the extreme deformation that can be taken up in the supracrustal rocks. Towards this boundary the tectonite fabric of the AQ D becomes further accentuated, and near its northern boundary the AQ D differs both chemically, mineralogically and structurally from the AQ D to the south of the shear zone. We have both found cumulaterocks originating from near the base of the original magmatic AQD complex and metavol canic rocks interpreted as belonging to its top part, whose less deformed equivalents are most probably covered by the Inland I ce. The chemical variation of the AQ D suite is wide and comparable to that of Cenozoic calcalkaline igneous suites. 


\section{Acknowledgements}

Concise reviews by Graham Leslie and Chris Pulvertaft and financial support by the Carlsberg Foundation are gratefully acknowledged. The Air Greenland helicopter pilot and the crew on board M /S M ilandt (Aasiaat) are thanked for efficient transport and practical help. Chemical analyses were carried out by XRF on glass discs at the D epartment of Earth Sciences, University of Aarhus, D enmark.

\section{References}

Bak, J., Grocott, J., Korstgård, J .A., N ash, D ., Sørensen K. \& Watterson, J. 1975a: Tectonic implications of Precambrian shear belts in western Greenland. N ature 254, 566-569.

Bak, J., Korstgård, J.[A.] \& Sørensen, K. 1975b: A major shear zone within the N agssugtogidian of W est Greenland. Tectonophysics 27, 191-209.

Best, M.G. 1982: I gneous and M etamorphic Petrology, 630 pp. San Francisco: W.H . Freeman.

Brady, J.B. 1974: C oexisting actinoliteand hornblendefrom West-Central N ew Hampshire. American M ineralogist 59, 529-535.

Clark, M .D . 1978: Amphibolitic rocksfrom the Precambrian of G rand Canyon: mineral chemistry and phase petrology. Mineralogical M agazine 42, 199-207.

Connelly, J.N ., van Gool, J.A.M . \& M engel, F.C. 2000:Temporal evolution of a deeply eroded orogen: the N agssugtoqidian 0 rogen, West Greenland. Canadian J ournal of Earth Sciences 37, 1121-1142.

Erikson, E.H . Jr. 1977: Petrology and petrogenesis of the M ount Stuart batholith - plutonic equivalent of the high-alumina basalt association?. Contributions to M ineralogy and Petrology 60, 183-207.

Escher, A. 1971: Geological Map of Greenland, 1:500 000, Søndre Strømfjord - N ûgssuaq, sheet 3. C openhagen: G eological Survey of Greenland.

Gagnevin, D ., Daly, J.S. \& Poli, G. 2004: Petrographic, geochemical and isotopic constraints on magma dynamics and mixing in the $M$ iocene $M$ onte $C$ apanne monzogranite(Elba Island, Italy). Lithos 78, 157-195.

H anmer, S., M engel, F., Connelly, J. \& van Gool, J.[A.M .] 1997a: Significance of crustal-scale shear zones and synkinematic dykes in the N agssugtogidian orogen, SW G reenland: a re-examination. Journal of Structural G eology 19, 59-75.

H anmer, S., M engel, F., Connelly, J. \& van G ool, J.[A.M .] 1997b: Significance of crustal-scale shear zones and synkinematic dykes in the N agssugtoqidian orogen, SW G reenland: a re examination. (C orrigendum). Journal of Structural Geology 19, I.

H aslam, H.W. \& Walker, B.G. 1971: A metamorphosed pyroxenite at Nero Hill, Central Tanzania. M ineralogical M agazine 38, 58-63.

H ealy, B., Collins, W.J \& \& Richards, S.W. 2004: A hybrid origin for the Lachlan S-type granites: the M urrumbidgee Batholith example. Lithos 78, 197-216.
H enderson, G. 1969: ThePrecambrian rocks of theEgedesminde-C hris tianshåb area (sheets 68V.1 and 68V.2). Rapport Grønlands G eologiske Undersøgelse 23, 1-37.

H ickman, M .H . \& G lassley, W.E. 1984:T herole of metamorphic fluid transport and the Rb-Sr isotopic resetting of shear zones: evidence from N ordre Strømfjord, West G reenland. Contributions to M ineralogy and Petrology 87, 265-281.

Janousek, J., Braithwaite, C.J.R., Bowes, D.R. \& Gerdes, A. 2004 $M$ agma-mixing in the genesis of $\mathrm{H}$ ercynian calc-alkaline granitoids: an integrated petrographic and geochemical study of the Sazava intrusion, Central Bohemian Pluton, Czech Republic. Lithos 78, 6799.

Kalsbeek, F. 2001: G eochemical comparison between Archaean and Proterozoic orthogneisses from the Nagssugtogidian orogen, West Greenland. Precambrian Research 105, 165-181.

Kalsbeek, F., Taylor, P.N . \& Henriksen, N . 1984: Age of rocks, structures and metamorphism in the $\mathrm{N}$ agssugtogidian mobilebelt - field and $\mathrm{Pb}$-isotopic evidence. Canadian Journal of Earth Sciences 21, 1126-1131.

Kalsbeek, F., Pidgeon, R.T. \& Taylor, P.N . 1987: N agssugtoqidian mobile belt of West Greenland: a cryptic $1850 \mathrm{M}$ a suture between two Archaean continents - chemical and isotopic evidence. Earth and Planetary Science Letters 85, 365-385.

M anatschal, G ., Ulfbeck, D .\& van G ool, J.[A.M .] 1998: C hange from thrusting to syncollisional extension at a mid-crustal level: an example from the Palaeoproterozoic Nagssugtoqidian Orogen (West Greenland). Canadian Journal of Earth Sciences 35, 802-819.

Nielsen, B.M . 2004: Crustal architecture and spatial distribution of mineral occurrences in the Precambrian shield of central West G reenland based on geophysical and geological data. D anmarks og $G$ rønlands $\mathrm{G}$ eologiske U ndersøgelse Rapport 2004/26, 63 pp. , 8 appendices. Ph.D. thesis, Department of Earth Sciences, University of Aarhus, D enmark.

Nielsen, B.M \& Rasmussen, T.M . 2004: M ineral resources of the Pre cambrian shield of central W est G reenland $\left(66^{\circ}\right.$ to $\left.70^{\circ} 15^{\prime} \mathrm{N}\right)$. Part 3. Implications of potential field data for the tectonic framework. D anmarks og Grønlands G eologiske U ndersøgelse Rapport 2004/ 21, 165 pp., 1 CD-ROM .

N oe-N ygaard, A.\& Ramberg, H . 1961: G eological reconnaissancemap of the country between latitudes $69^{\circ} \mathrm{N}$ and $63^{\circ} 45^{\prime} \mathrm{N}$, West Greenland. M eddelelser om Grønland 123, 1-9.

O lesen, N.Ø. 1984: Geological map of Greenland, 1:100 000, Agto, 67 V.1 N ord. Copenhagen: G eological Survey of Greenland.

Passchier, C.W., den Brok, S.W.J., van Gool, J.A.M., M arker, M. \& M anatschal, G. 1997: A laterally constricted shear zone system the N ordre Strømfjord steep belt, Nagssugtoqidian O rogen, W Greenland. Terra N ova 9, 199-202.

Ramberg, H . 1949: O n the petrogenesis of the gneiss complexes between Sukkertoppen and C hristianshaab, West Greenland. M eddelelser fra Dansk G eologisk Forening 11, 312-327.

Rasmussen, T.M . \& van G ool, J.A.M . 2000: Aeromagnetic survey in southern West G reenland: project Aer omag 1999. G eology of $G$ reenland Survey Bulletin 186, 73-77.

Sørensen, K. 1983: G rowth and dynamics of the N ordre Strømfjord Shear Zone. Journal of G eophysical Research 88, 3419-3437. 
Sørensen, K. \& W inter, J.D . 1989: D eformation and mass transport in the N ordre Strømfjord Shear Zone, Central West Greenland. In: B ridgwater, D . (ed.): Fluid movements - element transport and the composition of the deep crust, 171-185. Amsterdam: Kluwer Academic Publishers.

Steenfelt, A., Stendal, H., N ielsen, B.M . \& Rasmussen, T.M . 2004: Gold in central West $G$ reenland - known and prospective occurrences. Geological Survey of Denmark and Greenland Bulletin 4, 65-68.

Stendal, H ., N ielsen, B.M., Secher, K. \& Steenfelt, A. 2004: M ineral resources of the Precambrian shield of central West $G$ reenland $\left(66^{\circ}\right.$ to $70^{\circ} 15^{\prime} \mathrm{N}$ ). Part 2. M ineral occurrences. Danmarks og G rønlands G eologiskeU ndersøgelse R apport 2004/20, 212 pp.

Stendal, H ., Secher, K. \& Frei, R. 2006: ${ }^{207} \mathrm{~Pb}-{ }^{206} \mathrm{~Pb}$ dating of magnetite, monazite and allanite in the central and northern N agssugtogidian orogen, West G reenland. In: G arde, A.A.\& Kalsbeek, F. (eds): Precambrian crustal evolution and $C$ retaceous-Palaeogene faulting in W est Greenland. G eological Survey of Denmark and G reenland Bulletin 11, 101-114 (this volume).

Stephensen, N .C.N . \& H ensel, H .D. 1979: Intergrown calcic and Fe $\mathrm{Mg}$ amphiboles from the Wongwibinda metamorphic complex, N.S.W., Australia. Canadian M ineralogist 17, 11-23.

van Gool, J.A.M ., Kriegsman, L.M ., M arker, M . \& N ichols, G .T. 1999: Thrust stacking in the inner N ord re Strømfjord area, West G reenland: Significance for the tectonic evolution of the Palaeoproterozoic $\mathrm{N}$ agssugtoqidian orogen. Precambrian Research 93, 71-86.

van Gool, J.A.M ., Connelly, J.N ., M arker, M.\& M engel, F.C. 2002: The $N$ agssugtogidian Orogen of W est Greenland: tectonic evolution and regional correlations from a W est Greenland perspective. Canadian Journal of Earth Sciences 39, 665-686.

van Gool, J.A.M . \& M arker, M . 2004: Geological M ap of Greenland, 1:100 000, U ssuit, 67 V.2 N ord. C openhagen: Geological Survey of Denmark and Greenland. 
